\title{
Hypertension Induced by Aripiprazole Use in an Autistic Child Patient
}

\author{
Aylin Deniz Uzun, Şermin Yalın Sapmaz, Masum Öztürk, Hasan Kandemir \\ Department of Child and Adolescent Psychiatry, College of Medicine, Manisa Celal Bayar University, Manisa, Turkey
}

\begin{abstract}
Atypical antipsychotics in children and adolescents are widely used for aggression, emotional variability and psychosis treatment. Aripiprazole is also an atypical antipsychotic that increasingly used in children and adolescents with schizophrenia, autism and bipolar disorder. In this case report, a medically healthy patient with autism associated with behavioral problems is presented with the development of hypertension after the onset of aripiprazole and the return of blood pressure to normal levels after withdrawal of the drug. The purpose of this case study is to discuss and report the emergence of aripiprazole-induced hypertension as a side effect of drugs in children and adolescents.
\end{abstract}

KEY WORDS: Child; Hypertension; Autistic disorder; Aripiprazole.

\section{INTRODUCTION}

Autism spectrum disorder (ASD) is a neurodevelopmental disorder. There is no known efficacious pharmacotherapy for the core symptoms of ASD. Risperidone and aripiprazole are the only two medications approved by US Food and Drug Administration for irritability (aggression, self-injury, and severe tantrums) in children with ASD [1].

With this case report, we have aimed to present an 8-year old case with autism, which had developed hypertension due to aripiprazole use. Scarce reports exist in relevant literature, with our case being the sole patient with pre-pubertal onset.

\section{CASE}

A girl aged 7 years and 6 months following with the di-

Received: April 19, 2018 / Revised: July 20, 2018

Accepted: August 18, 2018

Address for correspondence: Aylin Deniz Uzun

Department of Child and Adolescent Psychiatry, Hafsa Sultan

Hospital, College of Medicine, Manisa Celal Bayar University,

Manisa, Turkey

E-mail: aylin.uzun@cbu.edu.tr

ORCID: https://orcid.org/0000-0002-0635-4593

*This case was presented as a poster in Turkish language in the 4. Prof. Dr. Selahattin Şenol Bahar Okulu between March 29, 2018 and April 1, 2018. agnosis of autism and mild mental retardation for 4 year. She applied with behavioral problems such as irritability (aggression, self-injury, and severe tantrums), inability to follow instructions and rules, repetitive and stereotypical movements, physically hurting her friends. First, psychoeducation was given to the family and behavioral suggestions were made. At the end of the 3rd month, due to the continuing problems a pharmacological treatment was started with $1 \mathrm{mg} /$ day aripiprazole that was used orally. Physical examination and laboratory tests, prior to treatment initiation revealed no problems in our case that had no comorbid physical illness. Body mass index (BMI) was $14.3 \mathrm{~kg} / \mathrm{m}^{2}$ (15-25th percentiles), blood pressure (BP) was $110 / 70 \mathrm{mmHg}(<90$ percentile), results of the markers that determine lipid profile, liver function tests, kidney function tests, cell blood count (CBC) values were within normal ranges. The case had no previous history of any medication use for behavior problems. Since the case has partial clinical symptomatic improvement with aripiprazole, medication dose was increased to $2 \mathrm{mg} /$ day after a month. With increased medication dosages, problematic behavioral and psychiatric symptoms of the case were completely eliminated and no side effect was described by the family. Symptoms or signs were not detected at monthly controls during the first 3 months. At the 6th month examination of her follow up (when 8 years old),

(ㄷ) This is an Open-Access article distributed under the terms of the Creative Commons Attribution Non-Commercial License (http://creativecommons.org/licenses/by-nc/4.0) which permits unrestricted non-commercial use, distribution, and reproduction in any medium, provided the original work is properly cited. 
her BMI was found as $18.1 \mathrm{~kg} / \mathrm{m}^{2}$ (75-85 percentiles), and $\mathrm{BP}$ was 130/90 $\mathrm{mmHg}$ (> 99 percentile). Her lipid profile, liver function tests, kidney function tests, CBC was found within normal limits. The case was consulted to a pediatrician and it was recommended that the family should monitor the case's BP values once a day, throughout one week. It was observed that her BP levels alternated during monitorization. On 4 days of the week, her $\mathrm{BP}$ values were measured as $130 / 90$ to $140 / 90 \mathrm{mmHg}$; while on 3 days, the values were around 100/60 to 110/70 mmHg. No endocrinological or renovascular etiology that would provide an explanation for this condition was determined. Elevated BP values were attributed to her medication use and it was recommended to cease her medication for some time, to observe her BP values. Following the cessation of her medication regimen, her BP measures were collected once a day, for one week, once again. It was seen that her BP values were regulated and around 100/60 to $100 / 70 \mathrm{mmHg}(<90$ th percentile).

BP values were assessed with 'BP Levels for Girls by Age and Height Percentile' [2].

\section{DISCUSSION}

With this case report, we have aimed to present the clinical course of a case that had developed asymptomatic hypertension at the 6th month of her low-dose aripiprazole use $2 \mathrm{mg} /$ day, and to discuss possible underlying mechanisms of this phenomenon.

Through a review of relevant literature, we came across 7 case reports that suggested aripiprazole use led to hypertension, in their clinical course and management of their cases [3-8]. Most of these cases, however, had some risk factors that might be attributed to the observed increase in their BP, such as old age [3,5-8] history of a metabolic disorder (diabetes mellitus, hypertension, coronary heart disease) and multiple drug use [5-7]. Among these reported cases, symptoms related to hypertension had developed upon either long-term medication use, or increasing the medication doses, which had led to the recognition of the condition [3-8]. Rather different than these cases, hypertension had emerged at 6th month of treatment in our case and was recognized during her routine hospital visits. Her elevated BP values were back in normal ranges, within 10 days after aripiprazole treatment had been ceased.

When data regarding effects of atypical antipsychotics in children, rates of weight gain as the side effect seem to be similar to those observed in adults, though the quantity of weight gain seem to be much more than what is seen in adults [9]. In one cross-sectional study, it was found that subjects that had used antipsychotics longer than 12 months had significantly higher BMI, compared to those that had used antipsychotics less than one month [10]. It has also been reported that among children where increase in the prevalence of essential hypertension correlated well with the increase in BMI, following add- on of the increase in the prevalence of obesity, pediatric hypertension turned into an epidemiological problem [11]. Even though BMI value of our case was not regarded as indicating obesity, there was a significant difference between BMI values that had been measured prior to the initiation of treatment and after, which was conceptualized as a risk factor for hypertension. However, BP values measured in normal ranges within 10 days upon medication cessation and no observed alteration in weight, shifted the attention to aripiprazole use as the main factor for developing hypertension.

Commonly reported action mechanism of aripiprazole involves a partial agonistic effect on D3 and $5 \mathrm{HT}_{1 \mathrm{~A}}$ receptors and an antagonistic effect on $5-\mathrm{HT}_{2 \mathrm{~A}}$ receptor [12]. Differently some authors such as Davies et al. [13] and Shapiro et al. [14] have suggested that aripiprazole might actually act as a partial agonist on $5-\mathrm{HT}_{2 \mathrm{~A}}$ receptor. $5-\mathrm{HT}_{2 \mathrm{~A}}$ receptor is known to have a role in the contraction functions of vascular smooth muscles. Therefore, it might be hypothesized that through aripiprazole acting as a partial agonist of $5-\mathrm{HT}_{2 \mathrm{~A}}$ receptors for some individuals, in turn, via causing vasoconstriction of vascular smooth muscles, caused elevated BP. One other reason for elevated $\mathrm{BP}$ measures might be related to the inhibition of nitric oxide (NO) release. In a study, it was shown that aripiprazole inhibited NO production in microglial cells [15]. NO is known to act as an agent that decreased BP. The hypertension could be occurred due to aripiprazole, because of inhibited NO production in the vessels. Along with these phenomena, it has also been suggested that through causing a structural alteration due to its effects on the endothelium; obesity might also decrease the bioavailability of nitric oxide and in turn, leading to emergence of hypertension [11]. Efficacy and side-effect pro- 
files of these drugs are heterogeneous, with large interindividual variability. Much of the interindividual variability in response and side effects is due to genetic factors.

Main difference in the course of our case was the fact that hypertension presented upon 6 months treatment, contrary to those reported to have developed upon acute use of the medication, and its asymptomatic nature and course in our patient. Moreover, to best of our knowledge, this has been the only case that reported such symptoms manifesting in a pre-pubertal case, so far. Clinicians need to be attentive and vigilant for this side-effect and it might be a good idea to monitor BP levels closely, if aripiprazole is to be chosen as the treatment agent. Further studies are warranted to explore and clearly identify through which mechanisms this side-effect occurs.

\section{- Conflicts of Interest}

No potential conflict of interest relevant to this article was reported.

\section{Author Contributions}

Conceptualization: Aylin Deniz Uzun, Şermin Yalın Sapmaz. Data acquisition: Aylin Deniz Uzun, Şermin Yalın Sapmaz, Masum Öztürk, Hasan Kandemir. Supervision: Şermin Yalın Sapmaz, Hasan Kandemir. Writing-original draft: Aylin Deniz Uzun, Şermin Yalın Sapmaz. Review \& editing: Masum Öztürk, Şermin Yalın Sapmaz, Hasan Kandemir.

\section{ORCID}

Aylin Deniz Uzun https://orcid.org/0000-0002-0635-4593

Şermin Yalın Sapmaz https://orcid.org/0000-0002-1084-5053

Masum Öztürk https://orcid.org/0000-0002-9989-7051

Hasan Kandemir https://orcid.org/0000-0002-1138-4973

\section{REFERENCES}

1. Goel R, Hong JS, Findling RL, Ji NY. An update on pharmacotherapy for autism spectrum disorder in children and adolescents. Int Rev Psychiatry 2018;30:78-95.

2. National High Blood Pressure Education Program Working Group on High Blood Pressure in Children and Adolescents.
The fourth report on the diagnosis, evaluation, and treatment of high blood pressure in children and adolescents. Pediatrics 2004; 114:555-576.

3. Borras L, Constant EL, Eytan A, Huguelet P. Hypertension and aripiprazole. Am J Psychiatry 2005;162:2392.

4. Bat-Pitault F, Delorme R. Aripiprazole and hypertension in adolescents. J Child Adolesc Psychopharmacol 2009; 19:601602.

5. Pitchot W, Ansseau M. Aripiprazole, hypertension, and confusion. J Neuropsychiatry Clin Neurosci 2010;22:123.E33.

6. Hsiao YL, Chen SJ, Shen TW, Chang CH, Chen ST. Aripiprazole augmentation induced hypertension in major depressive disorder: a case report. Prog Neuropsychopharmacol Biol Psychiatry 2011;35:305-306.

7. Yasui-Furukori N, Fujii A. Worsened hypertension control induced by aripiprazole. Neuropsychiatr Dis Treat 2013;9:505507.

8. Seven H, Ayhan MG, Kürkçü A, Özbek S, Eren İ. Aripiprazoleinduced asymptomatic hypertension: a case report. Psychopharmacol Bull 2017;47:53-56.

9. Correll CU, Carlson HE. Endocrine and metabolic adverse effects of psychotropic medications in children and adolescents. I Am Acad Child Adolesc Psychiatry 2006;45:771791.

10. Laita P, Cifuentes A, Doll A, Llorente C, Cortés I, Parellada M, et al. Antipsychotic-related abnormal involuntary movements and metabolic and endocrine side effects in children and adolescents. JChild Adolesc Psychopharmacol 2007; 17:487502.

11. Yegül Gülnar G, Kasap Demir B. Obesity-related hypertension mechanisms in children and adolescents. İzmir Katip Çelebi Univ Fac Health Sci J 2017;2:39-43.

12. Stahl SM. Stahl's essential psychopharmacology: neuroscientific basis and practical applications. 4th ed. New York:Cambrigde University Press,2013.

13. Davies MA, Sheffler DJ, Roth BL. Aripiprazole: a novel atypical antipsychotic drug with a uniquely robust pharmacology. CNS Drug Rev 2004;10:317-336.

14. Shapiro DA, Renock S, Arrington E, Chiodo LA, Liu LX, Sibley DR, et al. Aripiprazole, a novel atypical antipsychotic drug with a unique and robust pharmacology. Neuropsychopharmacology 2003;28:1400-1411.

15. Kato T, Mizoguchi Y, Monji A, Horikawa H, Suzuki SO, Seki $\mathrm{Y}$, et al. Inhibitory effects of aripiprazole on interferon- $\gamma$-induced microglial activation via intracellular Ca2+ regulation in vitro. J Neurochem 2008;106:815-825. 